\title{
Visual Management: mapping experiences from service blueprints in the remote scenario
}

Débora Wernke

Master's Degree, Universidade Federal de Santa Catarina / deborawernke@gmail.com $\underline{\text { lattes }}$

Júlio Monteiro Teixeira

PhD, Universidade Federal de Santa Catarina / julio.teixeira@ufsc.br

Orcid: 0000-0002-9464-2615 / lattes

Sent: 22/08/2020 // Accepted: 12/12/2020 


\title{
Visual Management: mapping experiences from service blueprints in the remote scenario
}

\begin{abstract}
Visual Management combined with Service Design tools is a good strategy for implementing process mapping in remote scenarios. The general objective of this study was to present its concepts and implement the service blueprint as a facilitating tool for mapping the experiences of processes in the Human Resources area. To provide the best interaction and practice of actions, an action research was carried out at the company Jungle Devs, mapping the entire journey of the selection process for new candidates. The methodological procedure was oriented by the guidelines of the exploratory research, starting from a systematic understanding of the processes that took place in person and from the analysis of the activities performed by the company. A greater understanding of the activities of the company's employees and of the interaction with the candidates was sought, thus identifying the problematic points and from these, the development of recommendations for improvement and formalization of the process in the remote mode. Visual Management through the blueprint service tool is known to be relevant to align time in this modality, in addition to facilitating the understanding of the process to the other employees of the company. Thus, an implementation of the service project as a visual tool was deployed to other processes, and from other areas, to reach their maturity in the face of company expansion.
\end{abstract}

Keywords: visual management. service blueprint. human resources. 


\title{
Gestão Visual: mapeando experiências a partir de blueprints de serviço no cenário remoto
}

\begin{abstract}
RESUMO
A Gestão Visual aliada às ferramentas de Design de Serviços mostra-se como uma boa estratégia para a implementação do mapeamento de processos em cenários remotos. $O$ objetivo geral do presente estudo foi apresentar seus conceitos e implementar o service blueprint como uma ferramenta facilitadora para o mapeamento de experiências dos processos da área de Recursos Humanos. Visando proporcionar a melhor interação e prática das ações, foi realizada a pesquisa-ação na empresa Jungle Devs, participando então do mapeamento de toda a jornada do processo de seleção de novos candidatos. O procedimento metodológico foi orientado pelas diretrizes da pesquisa exploratória, partindo de um entendimento sistemático dos processos que ocorriam presencialmente e da análise das atividades exercidas pela empresa. Buscou-se um maior entendimento das atividades dos colaboradores da empresa e da interação deles com os candidatos, identificando assim os pontos problemáticos e a partir destes, o desenvolvimento de recomendações para melhoria e formalização do processo na modalidade remota. A Gestão Visual por meio da ferramenta service blueprint mostrou-se relevante ao alinhamento do time nessa modalidade, além de facilitar o entendimento do processo aos demais colaboradores da empresa. Assim, a implementação do service blueprint como ferramenta visual foi desdobrada à demais processos, e de outras áreas, para que se atingisse a maturidade dos mesmos frente à expansão da empresa.
\end{abstract}

Palavras-chave: gestão visual. blueprint de serviço. recursos humanos. 


\title{
Gestión visual: mapeo de experiencias de blueprints de servicio en el escenario remoto
}

\begin{abstract}
RESUMEN
La gestión visual combinada con las herramientas de diseño de servicios es una buena estrategia para implementar el mapeo de procesos en escenarios remotos. El objetivo general de este estudio fue presentar sus conceptos e implementar el anteproyecto de servicio como herramienta facilitadora para mapear las experiencias de procesos en el área de Recursos Humanos. Con el fin de brindar la mejor interacción y práctica de acciones, se realizó investigación acción en la empresa Jungle Devs, participando luego en el mapeo de todo el recorrido del proceso de selección de nuevos candidatos. El procedimiento metodológico se guió por los lineamientos de investigación exploratoria, basados en una comprensión sistemática de los procesos que se llevaron a cabo en persona y el análisis de las actividades realizadas por la empresa. Se buscó un mayor conocimiento de las actividades de los empleados de la empresa y su interacción con los candidatos, identificando así los puntos problemáticos y a partir de éstos, el desarrollo de recomendaciones de mejora y formalización del proceso en modo remoto. La Gestión Visual a través de la herramienta de planos de servicio demostró ser relevante para la alineación del equipo en esta modalidad, además de facilitar la comprensión del proceso al resto de empleados de la empresa. Así, la implementación del blueprint del servicio como herramienta visual se desplegó a otros procesos, y desde otras áreas, para alcanzar su madurez de cara a la expansión de la empresa.
\end{abstract}

Palabras clave: gestión visual. blueprint de servicio. recursos humanos. 


\section{INTRODUCTION}

Remote work, previously announced as a tendency to be adopted by companies, was anticipated by the Covid-19 pandemic and continues to gain strength in the wait for the vaccine to control it. The return to face-to-face activities is postponed every month and the remote scenario continues to gain prominence. More applications emerge and more tools are rescued so that operations can be executed, minimizing the effects of the lack of face-to-face interaction.

The service sector has suffered more than the others by the fact that not all processes can be carried out remotely, while the technology sector has been showing resilience during the current world scenario. Companies were more easily adapted to the new context of work mode, given the daily use of the area product itself in company processes. Digital technologies become good allies for remote work and with it, this modality gains more and more adherence.

According to FGV (2020), the number of companies that intend to adopt remote work should grow 30\% after the quarantine period. In addition to security in pandemic times, research shows that this work model brings an increase of between $15 \%$ to $30 \%$ in employee productivity.

Companies like Google and Facebook have also extended remote work and others, however, saw this transition as an opportunity to adopt the modality making it an inevitable reality.

The research by Talenses Group (2020) shows how changes are taking place on four different fronts in companies with the COVID-19 scenario: home office, selection processes, training, and onboarding. The study was carried out between $03 / 27 / 20$ and $04 / 03 / 20$ and was answered by 375 HR professionals responsible for these topics within companies 
from different sectors (Commerce, Services, Industry, and Third Sector).

On average, only $8.8 \%$ of companies say that nothing has changed in relation to selection processes. On the other hand, $35.2 \%$ of the companies are carrying out the processes remotely, $8.8 \%$ maintained some in-person steps, $34.7 \%$ suspended all selection processes, while $12.5 \%$ are evaluating each case. In all sectors, more than $70 \%$ believe that the changes will remain fully or partially after the context of the pandemic (TALENSES GROUP, 2020).

The difficulties encountered stem from the forced transition and without planning the model, in which all the processes previously executed in a physical headquarters of the company were transferred to an online environment in remote work.

Still in the Brazilian panorama, there's a research done by Robert Half (2020), a specialized recruitment company that interviewed more than 800 professionals in Brazil about remote work and the future of work. Of the respondents, 78\% said they are working from home and also $86 \%$ would like to work remotely more often than before the pandemic. Asked what measures companies need to take as a result of the pandemic to the new normal, $91 \%$ expect companies to allow employees to work from home more often and $72 \%$ expect to hold fewer meetings and face-to-face training.

This reveals to us that all office functions can change as a result of the lessons we are learning while dealing with COVID-19. The physical workplace may even become the alternative, while the home office becomes the first option. (ROBERT HALF, 2020).

In view of the results, there is an inclination towards the continued adoption of remote means after the future return to face-to-face activities. Despite the benefits that accompany 
the remote modality, such as the autonomy and freedom acquired in this process, the linearity of the work must somehow also be transferred to this new environment. The functions previously performed in person move to this digital adaptation, gaining new ways of being performed and training for a future of mixed work after the pandemic.

In order to implement an adaptation for a process that meets this remote context and to be continued in a future mixed modality, an internship selection process was used as the object of study. That said, the objective of this study is to present concepts of Design and Visual Management to the Human Resources area and to implement the service blueprint as a facilitating tool in mapping the experiences of its processes.

For exploration, the company Jungle Devs was used as the source of the process, which adapted its processes to the remote context. Founded in February 2018 and based in Florianópolis, it operates in the area of software development and has a program to train professionals in the area of technology - Academy Program. This program refers to an internship and will serve as an object of analysis for the article.

\section{VISUAL MANAGEMENT, DESIGN E PROCESS}

Starting from the current context, where the transition from the physical work environment has moved to the digital environment with less planning, we can turn to the way the adaptations occurred and how the operations happened. What was once visible in a room, or easily shared by the swiveling of chairs between tables, has become a little more procedural. Remote work further underscores the need for clear communication and a continuous flow of knowledge to allow 
the continuity of processes, also with a view to agility.

In this scenario, Visual Management, which used to be part of the daily lives of several teams, changes to its online version and contributes to the visualization of teamwork. As work becomes more virtual, the importance of having wellcoordinated meetings increases, both face to face and in virtual settings. In any type of online meeting, keeping people involved is a tremendous challenge that active visualization tries to solve directly (SIBBET, 2013).

Visual Management was highlighted through the Lean philosophy, being disseminated and applied, mainly by intuitive communication systems in search of continuous improvement in the Toyota era. It was sometimes exemplified with the production lines and their control panels on the factory floors. Despite being previously physical, with the advancement of agile methodologies in the technology sector, visual techniques have been adapted to the online context. Currently we can count on a great diversity of applications and websites that have the facilities to handle a Visual Management tool in remote teams. Teixeira (2018) brings the concept of visualization through Visual Management tools as a guiding axis of project development processes.

According to PMBOK 5th ed., A process is defined as a set of interrelated actions and activities, which are performed to achieve a predefined product, result or service. Each process is characterized by its inputs, the tools and techniques that can be applied and the resulting outputs.

Project managers must always work on controlling situations, following deadlines and processes. But that does not mean that they need to be strict and act only by the rules of the PMBOK (ECHOS, 2018). The use of visual resources is opportune in this horizon, Design Thinking and its arsenal of tools, goes beyond the facilitation in meetings and projects 
and then focuses on contributing to a flexibility of the tools in the current scenario. Expanding the frontiers of design, creating greater interaction between professionals and allowing customization for different contexts.

The designer sees as a problem that which harms or prevents experience (emotional, cognitive and aesthetic) and well-being in people's lives. To recover such questions he organizes thinking in a structural and aesthetic way, this is the standard way of thinking of designers. (TEIXEIRA, 2018).

Thus, Design Thinking is then the mindset and the set of tools that we designers use to understand our specific users. This approach comes to innovate, be it a physical product or a digital product, a service, or another process that involves human interactions. Thus, it is necessary to map the culture, contexts, personal experiences and processes in the lives of individuals to think abductively and efficiently identify obstacles to generate more assertive solutions (VIANNA et al., 2012).

Being multidisciplinary and focused on the user, when applied to the development of services then we have Service Design. A structured approach that facilitates the creation of more useful and desirable processes for users, while at the same time, viable and efficient for those who execute them.

According to Stickdorn (2014), the Service Design approach refers to the design process and not to its final result, so a Service Design process can result from relatively abstract organizational structures, operational processes, service experiences, and even physical objects concrete.

The operational processes performed by the Human Resources area are here the services it provides to the organizational structure. Maintaining the culture and mainly recruiting, selecting and hiring the professionals who will integrate the company. Designing experiences related to the 
Human Resources area requires putting yourself in the shoes of the people who work for the company and the people who will apply for a position.

When mapping these experiences, we started to think about people, the difficulties they encounter, their goals, understanding their needs and aspirations to create joint solutions with those involved. Mapping experiences allows you to locate transitional volatility within a larger system of interactions and find innovative solutions to address it (KALBACH, 2017). A good journey must deliver, through culture and experiences, personal and professional development, as well as the well-being and attributes that the user needs as an individual. By offering the best experiences, companies increase their possibilities of retention, engagement and positioning in relation to their competitors.

Service Design can in turn help to understand and redesign aspects of the experience of the then collaborators and possible candidates. Users in the Human Resources area are also consumers, expect the same type of pleasant digital experiences, assertive and continuous experiences that are sometimes completely personalized.

Understanding the candidates' attitudes and behaviors turn necessary for a good selection process. A bad experience can increase dropout rates, which correspond to the number of people who start but do not finish filling out an application form and also change an organization's reputation as an employer (Employer Branding).

Thus, the role of design within the area aims to create better experiences, the difference is in the type of experience and for whom we are trying to improve this experience. Therefore, thinking about how a designer can transform the way we develop visual communication, redesign products or services, processes or strategies. 
The design aims at structuring the processes centered on the people who participate in it, bringing the concept of cocreation closer, making the participant feel belonging in the course and in the result of the work. Its holistic view, allows the process to be observed from different angles, thus allowing more reflections on it. In addition to having Visual Management supporting the alignment, fostering multidisciplinary teams can further promote the meeting of people from different areas and functions linked to the process, favoring the view from different angles and thus enabling greater detail.

\section{METHODOLOGICAL PROCEDURES}

To conduct the study, an exploratory method was selected. The nature of the problems dealt with in the field of Design often requires the researcher to get closer to the market in order to enable his understanding. After all, we are dealing with a discipline within the field of knowledge of "Applied" Social Sciences (SANTOS, 2018).

In the context of organizations, action research is appropriate when research seeks to describe the operations and development of actions over time for a specific group, community or management (COGHLAN and BRANNICK, 2001). In addition, action research seeks to understand how a member of a particular group performs an action, how and why that action can change or improve the functioning of a system and how the process of change or improvement allows for learning (COGHLAN and BRANNICK, 2001).

For the application of the research, the company Jungle Devs from its selection process for interns will be the object of study. The company belongs to the technology sector and 
operates in the area of development of digital products, having in addition to the full-time hires model, the Academy Program. This program refers to the internship modality and is aimed at training new professionals in the technology area.

The program lasts for one year and is focused on students from nearby universities who are at the beginning of their careers. Each quarter a new challenge, focused on learning theory in practice, including participation in real company projects. Today participants have specializations in Front-end Development, Back-end Development, iOS Development, Android Development and UI / UX Design.

Jungle Devs has a culture of learning as a major element in its way to manage the organization. Its objective is to disseminate its technology teaching culture whenever possible, either to people who are already part of the organization or to new and/or future members.

Culture reveals the conduct of a certain group, being for organizations as norms to be followed, which can be formalized and written as mission, vision and values and others in a more informal way, perceived by the individuals who live it and perceive its effects. For Schein (1989), one of the recognized authors when talking about organizational culture, the concept of organizational culture is:

The set of basic assumptions that a group invented, discovered or developed when learning how to deal with the problems of external adaptation and internal integration, and which worked well enough to be transmitted to new members as the correct way to perceive, think and feel, in relation to these problems (SCHEIN, 1989, p.12).

This learning culture also extends to the selection processes for the Academy Program. In it, participants can have access to the challenge platform, developed internally, to teach the first steps. Even if the candidate does not 
advance to the next stages, he can access the content and do the exercises for a possible future application. As a culture, the challenge is to increasingly extend internal learning experiences, through processes such as mentoring, to future candidates.

With the adoption of the applicant tracking system, Workable, came the need for the People and Culture team (a team similar to Human Resources) to review the current process and improve the experiences lived by both possible new members and the internal team that runs it the steps. In addition to identifying the necessary adaptations to the remote model for everyone involved in the process.

Recognized then, as a suitable object for the study of design tools applied to Human Resources processes.

\subsection{Service Blueprint}

Shostack (1984), proposed through her article the Service Blueprint, a tool that delivered a new way of structuring and visualizing services, more organized and systematic.

The root of most service problems is, in fact, the
lack of systematic design and control. The use
of a diagram can help a service developer not
only to identify problems in advance but also to
see the potential for new market opportunities
(SHOSTACK, 1989 apud KALBACH, 2017,
p.229).

The Services Blueprint is an adaptable tool, each professional can use it in the way that best suits the context, adding or removing sections. It is important to find a balance between the basic structure and the context to be applied so that you can visualize the journeys assertively, without unnecessary information that would make it difficult to map 
and visualize the whole.

As a tool, this work used the Services Blueprint, so that the selection process could be mapped as well as the experiences involved in the process. The tool is one of the types of value alignment diagram, which is presented chronologically and shows both sides of the value creation in a single view. Its application allows you to figure out all the phases of the customer's journey, their actions and reactions, and also the phases that happen within your company.

Mapping a process, in addition to being a nice way to understand all the steps necessary to complete your workflow and keep everyone involved aligned, is part of the task of an organization that seeks sustainable scalability.

Generally, process mapping is done to establish company execution standards or procedures. In this sense, the mapping of processes meets the identification of the main steps and decisions in a routine workflow in a visual way. It also controls the flow of information, materials and documents involved in the process and clarifies tasks, decisions and actions that are necessary at certain points in time (SANTOS et al., 2015).

However, the mapping of processes through design approaches goes beyond organizing the steps and understanding their relationships to optimize the process, seeking all the experiences that will be awakened at each step for each of those involved. In this way, user-centered thinking and the ability to empathize will be the basis for executing the alignment of culture and values to the process.

In addition to bring the benefit of making the process increasingly visual, through information design, according to Shedroff (2000), data can be organized and presented, transforming it into meaningful and valuable information, offering a necessary structure for them to express their 
capabilities.

A good information design reduces fatigue and errors in information processing, speeds up work and makes the information attractive and appropriate to the situation in which it presents itself (QUINTÃO; TRISKA, 2013).

\subsection{Presentation of design concepts and the service blueprint tool}

The exploratory phase delimited only the selection process in the internship modality for the development of this work, not extending to the mapping of the selective process for fulltime. Then, collaborative planning was sought, identifying team members and groups interested in the research and then proceeding to map the selection process. It should be noted that it is important that the people involved in the mapping are familiar with the process.

The team composed for mapping the selection process contains members who have degrees in different areas such as Automation Engineering, Production Engineering, Psychology and Design. In order to present the concepts that would be used for this task, screening was carried out on the principles that govern design, what its applications are, how it fits into the Human Resources area, and what tools could be used. After the compilation of this material, it was presented to the team to level the knowledge.

\subsection{Personas Mapping}

From the understanding of the tools that came from design, collaborative work began to build the personas linked to the internship modality as well as their pains, day to day 
and points of contact with the brand.

Personas are fictional profiles, often developed as a way of representing a specific group of people based on their common interests. They can be built as a group activity in the workshops. This facilitates discussions about specific segments of customers/users of the service (STICKDORN, 2014, p.181).

Those involved in the process were able to bring their perspectives according to the internal data linked to the Academy Program for the empathy workshop.

Figure 1 . Study about personas

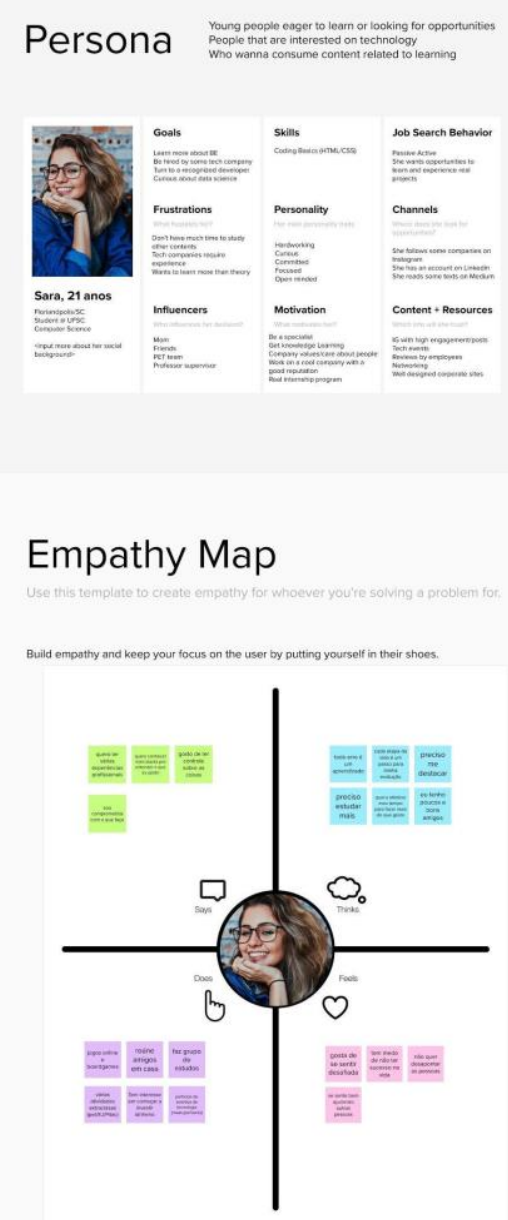

To-be Scenario Map

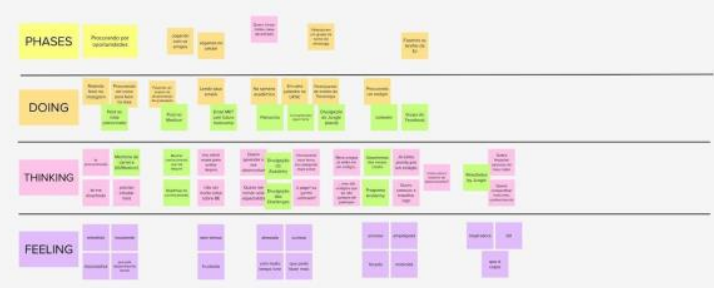

Journey
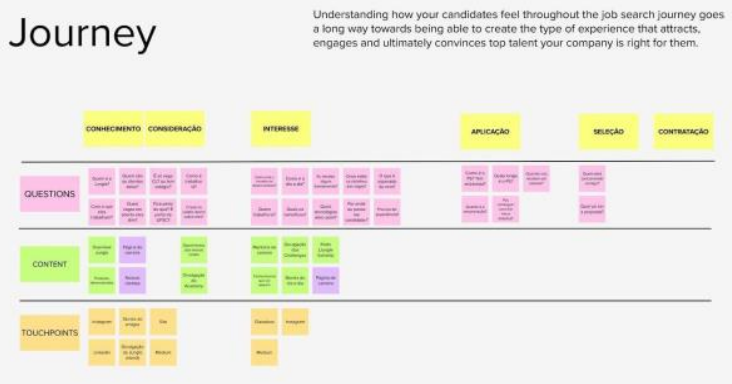

Source: Jungle Devs (2020).

At the end of the workshop, the information was validated 
with more people so that the stages could continue.

\subsection{Choice of a virtual tool}

Although we have the possibility of using digital tools to facilitate remote work, some teams may encounter some technical barriers. The applications are sometimes oriented to some type of specific software, they cannot be completely customized and, on the other hand, require a certain domain in order to use them.

Thinking of bringing a collaborative experience in real-time for this task, we used the website Mural.ly, which is an online visual collaboration platform. It allows writing on digital sticky notes, simulating the physical Post-its, allowing its movement or change of color and size. It also has an integrated timer that can count down to creative sessions.

Although Mural.ly already has a template for a service blueprint, the template provided follows the structure proposed by Practical Service Design which corresponds to a deeper service application. Therefore, for this mapping, a custom blueprint was used, made through the elements available on the website, described in the next step.

\subsection{Blueprint customization}

With the purpose of adapting the services blueprint to the mapping of a selection process, it was first sought to understand which streaks would need to be in the tool's structure. From the review of the process documents, the sections described in the image below were identified.

Figure 2. Blueprint structure of the selection process 


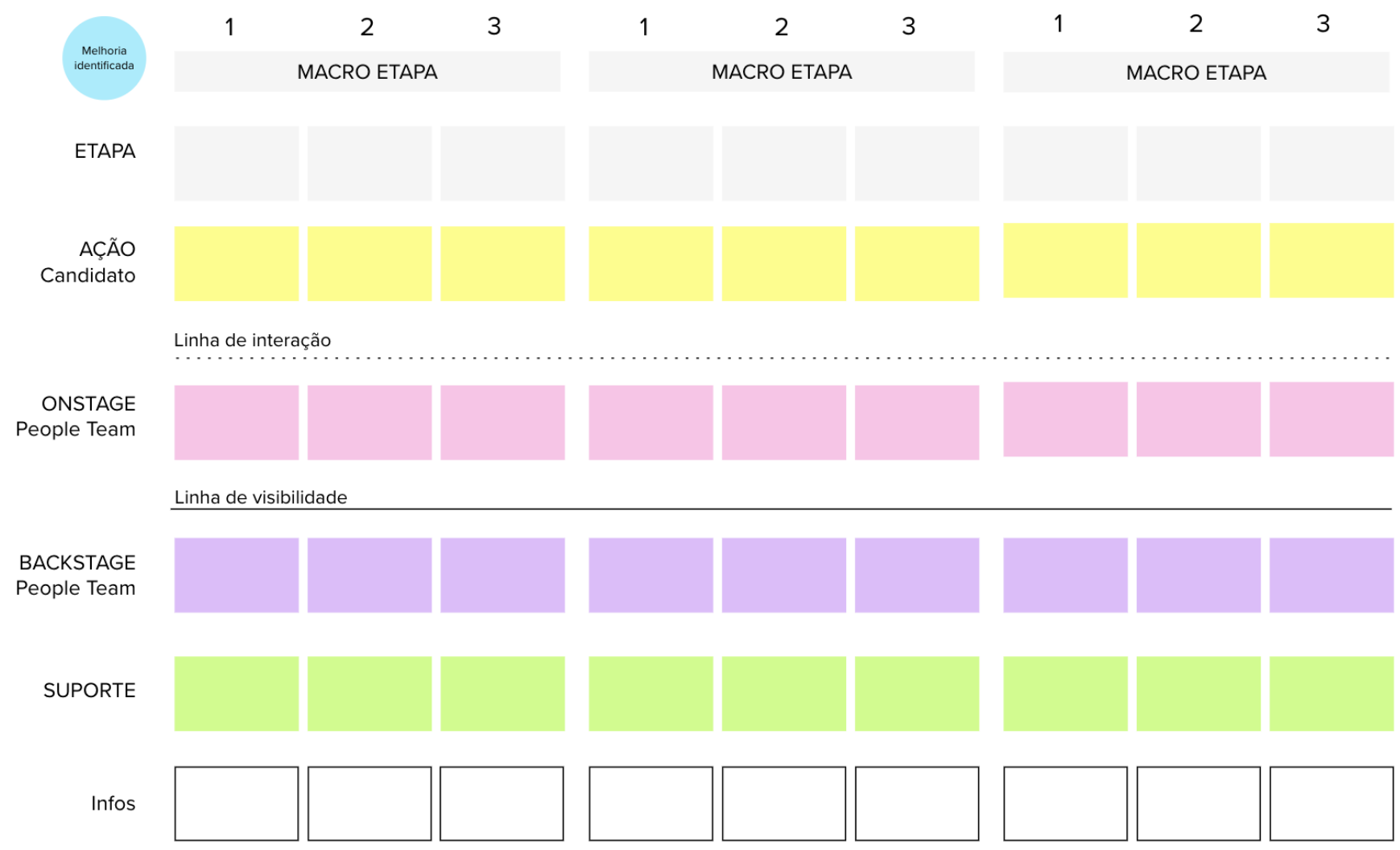

Source: Jungle Devs (2020).

In order for this customization to be possible, we tried to understand the points that needed to be highlighted, as well as the actors and people supporting the process in question:

- Macro steps: identified by the light gray bars, we tried to differentiate them so that after mapping it was possible to identify the improvement actions to be made in a value $x$ effort diagram.

- Steps: identified by the light gray notes, they are in the position of the physical evidence, here adapted to the scope of the process.

- Candidate Action: identified by the yellow notes are all interactions that the candidate has with the steps of the process. 
- Onstage People Team: identified by the pink notes, are all the interactions that the team has with the candidates.

- Backstage People Team: identified by the lilac notes are all the actions that happen internally in the team, that is, the candidates are not actors belonging to the action.

- Support: identified by the green notes are all actions that take place between the team and support actors, such as people from other teams or external service providers.

- Infos: identified by the white notes, they are complementary information that must accompany the artifacts and/or templates linked to the stage.

- Improvements: identified by circular notes in blue are the improvements identified during the mapping.

The intention of this initial mapping is to create a lowfidelity version, and once the steps are defined, redesign it on another platform in order to become the official documentation of the process.

For this particular job, the selection process for the internship (Academy Program) was chosen, which already had a structure previously documented in .doc format, which is available to everyone on the team. From the identification of the stages and macro-stages, the filling out of the blueprint began in the areas indicated by gray.

\section{RESULTS}

From each step, the corresponding actions were detailed in each of the lanes in a vertical direction. Lanes that did not actively participate in the stage were left blank, thus continuing until the end of the process. It was noted that the use of a visual tool allowed the identification of stages 
previously not described, leading the team to a better understanding of the flow.

Previously, the SIPOC tool was used, which works to improve processes, punctuating the entries and exits in the form of a table. This technique aims to improve the visualization of the sequence of processes by all members of the company directly linked to them (ANDRADE et al., 2012). However, this tool did not present the visualization of the chaining of steps followed by the candidates, disregarding their experiences. Thus making it impossible to understand the total flow of the process and to understand the real needs of the participants in the selection.

The whole visualization, favored by the blueprint, fostered a holistic view on the part of all involved. Therefore, such steps were added between the equivalent sections, filling them with the actions in the top-down direction.

Figure 3. Blueprint of the selection process created on Mural.ly

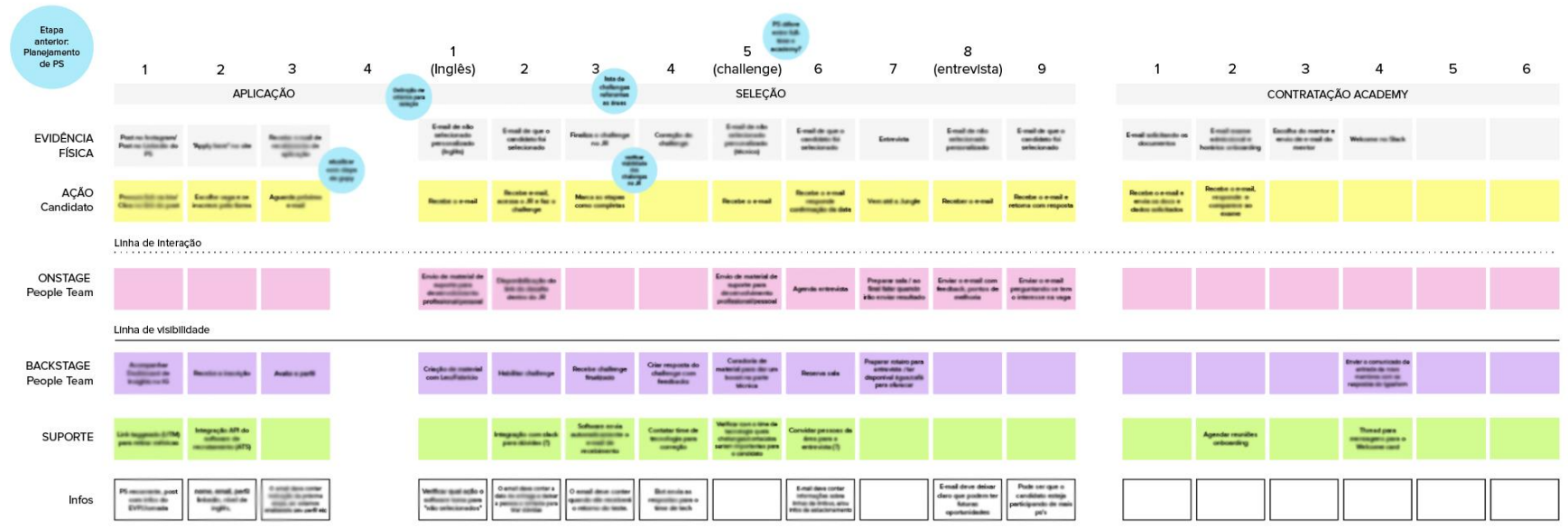

Source: Jungle Devs (2020).

At the end of the mapping through the service blueprint, feedback was collected from people who had just gone through the process, in order to add possible new improvements not yet identified by the work team for the 
remote mode.

In addition to the improvements, steps that were not previously described in the documentation made using SIPOC were identified, such as steps that were adapted to the online context and the entire sequence of contact that candidates have with the steps in the process. From a better understanding of the personas and later the use of the service blueprint, it was possible to identify which steps were not delivering an experience aligned with the company's culture and thus were listed for updates in the process. This result reinforced in practice how the focus of service design organizes the experiences, going beyond the simple sequencing of steps, delivering an easy visualization and also value to all actors participating in the process.

It is important to emphasize that the mapping will not only serve so that the candidate's experience is aligned with the proposal of the process in question, but also that the experience of the team that executes the process is convenient. One of the biggest gains of this mapping was the sequence of actions for the pre-employment medical test, necessary for the macro hiring stage. This was previously presented only as a step called "Medical Test", but in reality, it cost four steps with sequential sending of information until the appointment was definitively scheduled. With the identification of this bottleneck, there was an opportunity to optimize the process, reconfiguring the schedule, making it more independent and less dull for the team and also for the candidate.

The bad experiences of the candidates are usually due to an internal organizational deficiency or the lack of information in the communication that is sent. Unlike SIPOC, which did not provide such a clear journey to the team, the service blueprint managed to expose a visual panorama by offering a 
map of dependencies and thus allowing the bad experience to be revised.

From the information verified in each step and the alleged doubts on the part of the candidates in the Persona Mapping stage, the artifacts that would integrate the steps were listed, such as email templates, presentations, and guidelines for the teams that interact with the steps give feedback.

In the end, the process, already with the improvement items, was put into iteration within the applicant tracking system (Workable), and thus it is possible to adjust the steps and artifacts so that the process could run in a more scalable way.

\section{FINAL CONSIDERATIONS}

Although this cycle of using the blueprint has ended, the next steps should be the continuous iteration of the process. Always returning to the scope so that from the feedback received, it is possible to refine it over time.

Following the steps previously described offered the whole team, in addition to practice with the tool, a general and linear view of the process in evidence. The global visualization of the process propagates the design perspective, favoring the candidate's experience. Those involved in the process start to see the process as a whole and stop worrying about its specific steps.

The use of the interactive tool - Mural.ly - ensured that everyone could share their ideas in real-time, allowing more process reviews like these to be made on the remote model. This Visual Management of the process, linked to the principles of design, can organize the information collected and plan its final presentation. 
The process centered on the study of the candidate's behaviors brought the team closer and engaged them to exercise more and more the notions of empathy that Design Thinking proposes. The services blueprint proved to be a visual tool that, in addition to bringing the team closer to identify bottlenecks and improvements, makes the understanding of internal processes with a chronological approach, improving the understanding of sequential steps and actions that need to be taken.

\section{REFERENCES}

ANDRADE, Gabriela Exupery Virga de et al. Análise da aplicação conjunta das técnicas SIPOC, Fluxograma e FTA em uma empresa de médio porte. XXXII Encontro Nacional de Engenharia de Produção. Bento Gonçalves/RS. - Out. 2012. Disponível em: http://www.abepro.org.br/biblioteca/ENEGEP2012_TN_WIC_157_9 20_20681.pdf. Acesso em: 22 dez. 2020.

DIÁRIO DO COMÉRCIO. Home office será mantido por mais de $\mathbf{7 0 \%}$ das empresas no pós-crise. Disponível em: https://dcomercio.com.br/categoria/gestao/home-office-seramantido-por-mais-de-70-das-empresas-no-pos-crise. Acesso em 1 ago. 2020.

ECHOS. Gestão de projetos: como o design thinking pode ajudar? Disponível em: https://escoladesignthinking.echos.cc/blog/2018/03/gestao-deprojetos-como-o-design-thinking-pode-ajudar/. Acesso em 1 ago. 2020.

FINANCIAL TIMES. Why HR chiefs must rethink talent management after Covid-19. Disponível em: https://www.ft.com/content/71ad5416-a4a4-11ea-81ac4854aed294e5. Acesso em: 31 jul. 2020.

$\mathrm{KALBACH}, \mathrm{J}$. Mapeamento de Experiências, Um guia para criar valor por meio de jornadas, blueprints e diagramas. Rio de Janeiro: Alta Books Editora. 2017

SANTOS, Lucas Almeida dos et al. Mapeamento de processos: um estudo no ramo de serviços. Iberoamerican Journal of Industrial Engineering. Florianópolis, p. 108-128. jan. 2015.

PMI. Um guia do conhecimento em gerenciamento de projetos (guia PMBOK®). Project Management Institute, 5. ed, Saraiva, 2013.

QUINTÃO, Fernanda S.; TRISKA, Ricardo. Design de informação em interfaces digitais: origens, definições e fundamentos. 
Revista Brasileira de Design da Informação, São Paulo, v. 10, n. 2, p. 105-118, 2013.

ROBERT HALF. Home office agrada a maioria: como será a volta ao escritório? Disponível em: https://www.roberthalf.com.br/blog/tendencias/home-officeagrada-maioria-como-sera-volta-ao-escritorio. Acesso em 2 ago. 2020.

SANTOS, Aguinaldo dos. Seleção do método de pesquisa: guia para pós-graduando em design e áreas afins / Aguinaldo dos Santos. Curitiba, PR: Editora Insight, 2018. 230 p.

SHEDROFF, N. Information interaction design: a unified field theory of design. In: JACOBSON, Robert (ed.). Information design. Cambridge (MA): The MIT Press, 2000.

SCHEIN, Edgar H. Organizational culture and leadership. San Francisco, Jossey Bass, 1989.

SIBBET, D. Reuniões Visuais: como gráficos, lembretes autoadesivos e mapeamento de ideias podem transformar a produtividade de um grupo. Rio de Janeiro: Alta Books, 2013.

STICKDORN, Marc; SCHNEIDER, Jakob (Org.). Isto é Design Thinking de Serviços. Porto Alegre: Bookman, 2014.

TALENSES. Pesquisa | Processos de admissão, onboarding e treinamento no cenário COVID-19. Disponível em: https://talenses.com/pt/publicacoes/news-that-matter/pesquisaprocessos-de-admissao-onboarding-e-treinamento-no-cenariocovid-19. Acesso em 1 ago. 2020.

THIOLLENT, M. Metodologia da Pesquisa-Ação. 18a ed. São Paulo: Cortez, 2011.

VIANNA, M. et al. Design Thinking: Inovação em negócios. Rio de Janeiro: MJV Press, 2012. $161 \mathrm{p}$. 